\title{
Consumer innovativeness among females in specific fashion stores in the Menlyn shopping centre
}

\author{
Yolanda Jordaan and Michelle N Simpson
}

\section{OPSOMMING}

In die beginfase van die produklewensiklus neem sekere verbruikers, beter bekend as innoveerders, innovasies aan. Die verbruikersinnoveerder speel ' $n$ prominente rol in die diffusie en uiteindelike aanvaarding van nuwe produkte. Hierdie artikel ondersoek verbruikersinnoverendheid onder vroue in die konteks van die modebedryf. Resultate wys positiewe verwantskappe tussen verbruikers se mode-innoverendheid en mode-opinieleierskap, modebetrokkenheid en die behoefte vir uniekheid. ' $n$ Aanbeveling word gemaak dat kleinhandelaars in die modebedryf unieke en doelgemaakte aanbiedinge moet ontwikkel ten einde die behoeftes en begeertes van innoveerders te vervul.

\section{- Prof Yolanda Jordaan}

Department of Marketing and Communication Management

University of Pretoria

\section{- Ms Michelle N Simpson}

Department of Marketing and Communication Management

University of Pretoria

\section{INTRODUCTION}

The pace of technological advances, coupled with the consumer's receptivity to progress and newness, is shortening the life cycles of established products and placing a premium on new products. Since product innovation is critical for survival in any business, understanding the cumulative effects of innovation is particularly important because the rate of product innovation is higher than it has ever been (Alpert, 1994).

McCarthy et al (1999) state that the ability of marketers to identify innovators has a direct influence on the success or failure of new product introductions. Consumer innovators (the first people within a community to buy new products) reflect more favourable new product attitudes and are more swayed by newness appeals than later buyers (Robertson, 1971:15). This suggests that the innovator concept may provide a valid and meaningful approach to market segmentation.

The purpose of this article is to examine consumer innovativeness in the context of the fashion industry. Consumer innovativeness is conceptualised as the predisposition to buy new and different products rather than remain with previous choices and consumption patterns (Im et al, 2003). Consumer fashion innovators represent a valuable market segment for future marketers to target, since they provide much of the revenue needed to fund the development costs associated with bringing a new fashion to the market, and they influence the adoption and diffusion of fashions within a social group. The article provides a theoretical overview of consumer innovation and its relation to opinion leadership, product involvement and the need for uniqueness. This is followed by the presentation of the research design, analyses and results. The article also offers a discussion on the implications of the research for fashion retailers or managers. Finally, the article highlights the limitations of the research and identifies possible future research areas.

\section{LITERATURE REVIEW}

\section{Diffusion of innovation and consumer innovativeness}

Diffusion of innovation, a process by which innovations (new ideas, products and tastes) are accepted and spread throughout a market, has long been of concern to researchers in the social sciences (Hawkins et al, 1998:251). The diffusion research that resulted from this concern has given rise to the conceptual framework for the theory of adoption and diffu- 
sion of innovation (Baumgarten, 1975; Martinez et al, 1998).

The adoption of new products or services in the market is related to consumer innovativeness (Goldsmith \& Flynn, 1992). Several different conceptualisations of consumer innovativeness have been proposed over the years. Im et al (2003:62) view consumer innovativeness as "the predisposition to buy new and different products and brands rather than remain with previous choices and consumption patterns". Rogers (1995:22) defines innovativeness as "the degree to which an individual is relatively earlier in adopting new ideas than other members of his/her social system".

In line with the latter definition, innovativeness has been measured using the time of adoption method, which segments adopters into groups ranging from innovators, early adopters, early and late majority to laggards (Goldsmith \& Flynn, 1992). This method identifies innovators as those who purchase within (a certain period after product launch, or those who constitute the first $(x)$ per cent of a given market of purchase. Beaudoin et al (2003) are more specific and identify innovators as the first 2,5 per cent of respondents in a given market.

Research findings indicate that innovators have certain characteristics. Highly innovative people tend to take more risks, show greater social participation, have higher opinion leadership scores, be more knowledgeable about new products and more involved in the product category, have greater media exposure, and be heavier users of the product category (Goldsmith et al, 1987; Chau \& Hui, 1998; Pastore, 1999). They also seem to be female, younger in age and have higher incomes and higher levels of education (Leung, 1998).

As mentioned previously, consumer innovators are the first buyers of new products in the market, thus initiating the diffusion process. Research findings show that highly innovative people tend to be more likely to adopt new products than people with a low level of general innovativeness (Goldsmith \& Newell, 1997). These consumer innovators generate revenue for companies when they buy new products, and they play an important role in spreading information about the new product through word-of-mouth.

Many businesses strive towards maximum product diffusion in the hope of achieving the greatest possible number of adopters or the largest possible market share in the shortest possible period of time. Instead of measuring consumer innovativeness using the time of adoption method, Goldsmith and Hofacker (1991) proposed that consumer innovativeness be measured directly, in the same way that attitudes, lifestyles and personality are measured, but in a domain-specific environment. Innovativeness does not reflect buying behaviour only, but also the tendency to learn about and adopt innovations within specific domains of interest (Midgley \& Dowling, 1978). The next section investigates fashion as a domain of interest for the measurement of consumer innovativeness.

\section{Fashion as a domain of interest}

There is evidence that innovativeness is domainspecific, which means that consumers tend to be innovators for a specific product or product category (Goldsmith \& Newell, 1997). Muzinich et al (2003) believe that it is difficult to generalise innovative behaviour across product categories and that such behaviour can be better understood and predicted when the domain is limited to a specific product category. This is because one may find that consumers who are likely to adopt the latest new product in one field may be laggards in another (Goldsmith et al, 1998). Fashion is one area found to be highly important in the diffusion of innovation, and the frequent introduction of new styles makes the fashion market a highly desirable arena for diffusion studies focusing on innovativeness (Goldsmith et al, 1998).

Fashion can refer to the process by which styles are introduced and accepted by consumers, and also to a particular style that is accepted by a large group of consumers at a particular time (Kaiser, 1997:18). Muzinich et al (2003) elaborate on this by suggesting that fashion is a socially valued or universal standard of taste that also incorporates the singularity and subjectivity of individual tastes. Whatever one's take on fashion, fashion innovators help facilitate the spread of new fashion clothing, so that an understanding of this group should contribute to the development of new strategies to speed up adoption, and increase sales and profits.

Given the evidence that innovativeness is domain specific, a decision was made to focus on fashion as the domain of interest for this study. Furthermore, fashion (specifically clothing) is seen as very relevant because of its symbolic properties and accessibility to most consumers. Previous research findings indicate that certain variables are positively correlated with domain innovativeness (Goldsmith et al, 1996; Goldsmith et al, 1998; Roehrich, 2002). These variables, namely opinion leadership, product involvement and need for uniqueness are discussed below within the context of the fashion industry.

\section{Opinion leadership}

One of the major findings on consumer innovativeness is that it is positively associated with opinion leadership (Goldsmith et al, 1996). According to Feick and Price (1987), opinion leaders are individuals who act as information brokers intervening between mass media sources and the opinions and choices of the population. They often have a substantial effect on the diffusion of a product throughout its intended market. This is because an opinion leader is a person who exerts disproportionate influence on others through interpersonal communication. Opinion leaders appear to be more knowledgeable about, and involved with, the product class. These consumers are therefore very important to marketers in distributing product information. 
Opinion leaders are more likely to be found in product categories in which pleasure or satisfaction is derived from product usage or where the association with the product provides a form of self-expression, such as clothing (Darley, 1999). An unequivocal finding across many fashion studies is that fashion innovators are very likely to serve as fashion opinion leaders (Summers, 1971; Goldsmith \& Stith, 1992; Goldsmith, 1998). Fashion leaders can be described as those who are more interested in fashion than other consumers in the market, who are more confident of their own taste, who are the first to purchase new styles and, above all, who influence other consumers to adopt and buy new fashion items (Beaudion et al, 1998). Fashion leaders may verbally influence others and they do influence later fashion consumers by providing exposure to new styles, if in no other way. In terms of behavioural expression of fashion leadership, fashion leaders tend to spend more money on clothes and shop more often than other consumers, read more fashion magazines than do non-leaders, and tend to buy more clothes on impulse than other fashion consumers (Beaudoin et al, 1998).

\section{Product involvement}

As mentioned earlier, there seems to be a positive correlation between domain-specific innovativeness and product involvement (Goldsmith et al, 1998). Rothschild (in Goldsmith \& Emmert, 1991:364) defined involvement as "a state of motivation, arousal or interest, evoked by a particular stimulus or situation, displaying drive properties". Product involvement is important in understanding consumer attitudes and behaviour because involvement is a central motivating factor that shapes the purchase decision-making process. Involved consumers exhibit feelings of interest, pleasure and enthusiasm towards relevant product categories. Consumers will thus become involved when the object of interest is perceived as important in meeting needs, goals and values (Kim et al, 2002).

Clothing has frequently been recognised as a product category likely to induce high involvement because of its symbolic nature (Kim et al, 2002). Clothing involvement refers to the amount of time and effort a consumer spends in the selection of clothing. This high involvement may be because fashion clothing's continual and cyclical nature implies that consumers are often drawn into the style or fashion of the moment, or that they are people who attach a great deal of importance to their clothing (O'Cass, 2004).

Involvement has been discussed and utilised to examine fashion clothing in a number of prior studies (Browne \& Kaldenberg, 1997; Flynn \& Goldsmith, 1993). Consumers' involvement in fashion clothing can be viewed as a continuum from total attachment with fashion clothing and related activities (high involvement) to complete detachment (low involvement). Fashion involvement focuses on a consumer's interaction with fashion clothing as the stimulus in the marketplace. The more important fashion clothing is in a consumer's life, the greater the involvement with a product such as fashion clothing. Behavioural out- comes associated with product involvement include frequent purchase and use of a product, increased acquisition of product information, and frequent care of a product (Kim et al, 2002).

\section{Need for uniqueness}

Fromkin (in Roehrich, 2002) was the first to suggest a link between innovativeness and the need for uniqueness. According to Fromkin, the need for uniqueness pushes the individual to distinguish himself/herself through the possession of rare items. Snyder and Fromkin (in Roehrich, 2002) suggest three consequences of the need for uniqueness: the absence of interest in the reaction of others to one's own different ideas or acts; the desire not to always follow the rules; and the willingness to publicly defend one's opinions.

The external expression of an individual's need for uniqueness, which is the outcome of a social comparison process, depends on the individual's selfperceived degree of uniqueness relative to others. Through this social comparison process, individuals compare themselves with others (groups or individuals), thereby providing themselves with a frame of reference within which future decision-making behaviour can occur. This process consists of comparing the present state with some ideal state defined by the individual, dependent on the strength of his/her need for uniqueness. An individual's self-perceived degree of uniqueness is a reflection of how closely that individual perceives himself/herself to resemble others at the present time (Burns \& Warren, 1995).

Burns and Krampf (in Roehrich, 2002) observed that individuals with high needs for uniqueness were more apt to adopt new products than were individuals with low needs for uniqueness. The need for uniqueness is therefore a credible antecedent of innovativeness. Firstly, because innovativeness is an easy way to satisfy the need for uniqueness and, secondly, because the need for uniqueness includes independence in judgement, which is necessary for innovative purchasing (Roehrich, 2002).

The need for uniqueness may manifest in the buying of fashionable clothing. First, if individuals perceive themselves as having insufficient personal uniqueness, they will be prompted to pursue activities (such as buying fashionable clothes), which may have the potential to rectify this undesirable situation. Furthermore, individuals with stronger needs for uniqueness would be more likely to desire consumer choices which may be viewed as non-traditional, such as buying new fashion clothing from a channel through which the need for uniqueness can be manifested, such as a boutique (Burns \& Warren, 1995).

The next section identifies the research problem and objectives, based on the above discussion of consumer innovativeness and its correlation with opinion leadership, product involvement and the need for uniqueness. 


\section{RESEARCH PROBLEM AND OBJECTIVES}

While several international studies have investigated consumer innovativeness and its correlation with opinion leadership, product involvement and need for uniqueness (Goldsmith et al, 1987; Goldsmith et al, 1996; Goldsmith \& Newell, 1997; Chau \& Hui, 1998; Goldsmith et al, 1998; Leung, 1998; Pastore, 1999; Roehrich, 2002), similar studies have not been conducted in South Africa. The research problem can therefore be formulated as a lack of knowledge and understanding of consumer innovativeness in the fashion industry in a South African context. Because it is considered very important for businesses to reach innovators, who influence later adopters, account for initial levels of penetration and influence retail product offerings, the research objectives were to determine whether positive correlations exist between consumer fashion innovativeness and fashion opinion leadership, product involvement and need for fashion uniqueness. Figure 1 presents a proposed model of the research objectives.

The scope for the study was, firstly, limited to females in the domain of the fashion clothing industry because previous research has shown that females (1): tend to be more innovative than males; (2) are more involved in fashion than their male counterparts and (3) place fashion clothing in a more central position in their lives because of fashion clothing's feminine image (Tigert et al, 1980; Goldsmith et al, 1996; Browne \& Kaldenberg, 1997; Auty \& Elliott, 1998; O'Cass, 2004; Ha \& Stoel, 2004). Secondly, the study aimed to involve young females because findings from previous research studies indicated that fashion leaders are more likely to be young (Gutman \& Mills, 1982; Horridge \& Richards, 1984; Goldsmith \& Hofacker, 1991; Beaudion et al, 1998) and that they have an affinity for fashion products that allow for the expression of their uniqueness (Parker et al, 2004). Thirdly, based on fashion clothing as the domain for the survey, a decision was made to involve females shopping at Young Designers Emporium (YDE) and RJL in the Menlyn Shopping Centre because these stores offer unique fashion items and target the younger, fashionconscious consumer.

\section{RESEARCH METHODLOGY}

\section{Hypotheses and measurement instruments}

As mentioned previously, research findings indicate that opinion leadership, product involvement and need for uniqueness relate positively to domain innovativeness (Goldsmith et al, 1996; Goldsmith et al, 1998; Roehrich, 2002). On this basis, the following hypotheses were formulated:

$\mathrm{H}_{1}$ : Consumer fashion innovativeness is positively correlated with fashion opinion leadership.

$\mathrm{H}_{2}$ : Consumer fashion innovativeness is positively correlated with product involvement in clothing fashion.

$\mathrm{H}_{3}$ : Consumer fashion innovativeness is positively correlated with a need for fashion uniqueness.

The measurement instrument consisted of a selfcompletion questionnaire. The main body of the questionnaire was in the form of evaluative statements measuring the constructs identified from the relevant literature and the questionnaire mainly made use of five-point ascending Likert-type scales. Four established scales were used to measure the different constructs. The Domain Specific Innovativeness Scale (DSI) was used to measure consumer fashion innovativeness (Goldsmith et al, 1998); the revised Opinion Leadership Scale to measure fashion opinion leadership (Feick \& Price, 1987); a product involvement scale to measure involvement in clothing fashion (Mittal \& Lee, 1989); and the Roehrich scale to measure the need for fashion uniqueness (Roehrich, 2002).

The DSI scale was developed and validated by Goldsmith and Hofacker (1991). It is a balanced scale with three positively and three negatively worded items using a five-point response format. Several studies have shown the DSI to be reliable (between 0,81 and $0,86)$, valid, internally consistent and free from social

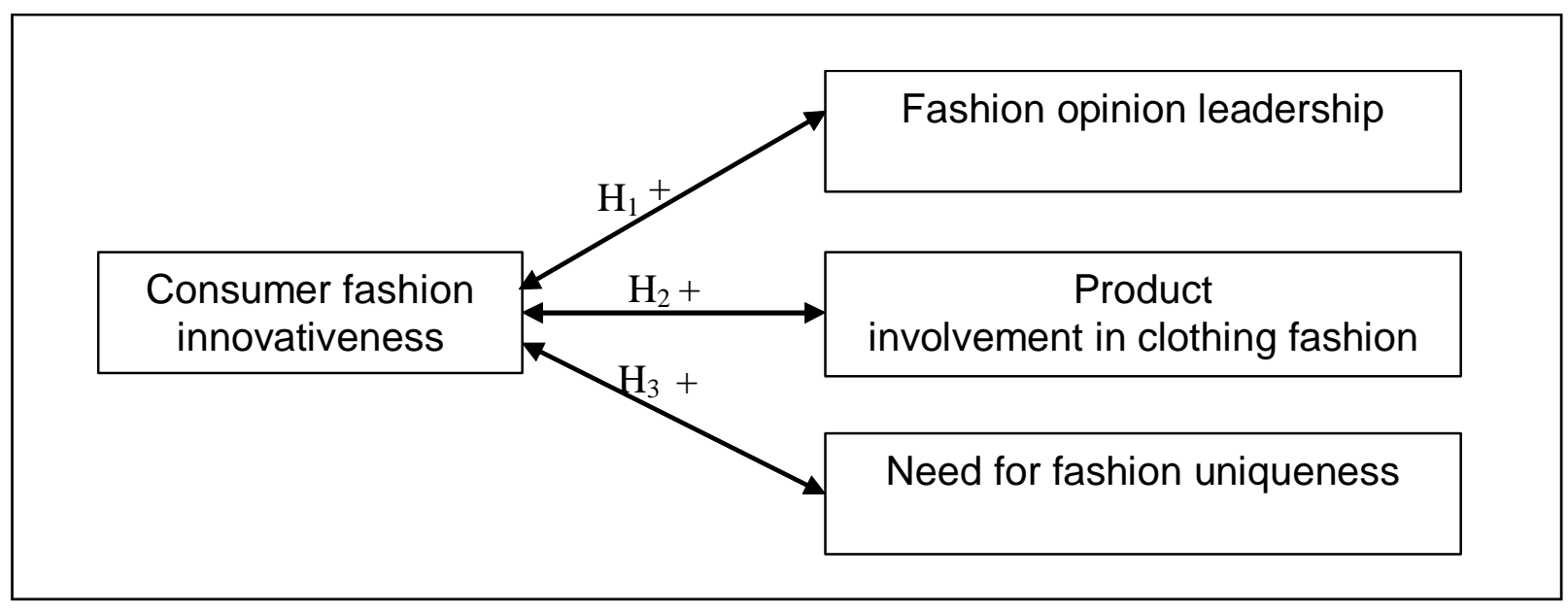

FIGURE 1: PROPOSED INNOVATIVENESS MODEL 
desirability bias (Bearden et al, 1993:59). The wording of the scale items was adapted to make them appropriate to a fashion context.

The Opinion Leadership Scale contains seven items that are adaptable to different product categories. Childers (in Bearden et al, 1993:40) recommended the deletion of item number five on the scale because it improved the internal consistency estimate (to 0,83). Therefore, the revised scale was used without the original item number five to form a six-item scale. All items were worded to be appropriate to a fashion context and measured using a five-point response format.

Product involvement was measured using a three-item scale developed through a number of pilot studies by Mittal and Lee (1989). The questions were again adapted to be relevant to the category of fashion and presented in a five-point response format. Mittal and Lee report high correlation between two occasion measures of product involvement $(r=0,70, p<0,01)$, showing test-retest reliability.

The Roehrich innovativeness scale was used to measure the need for uniqueness. Several studies confirmed that the internal consistency, trait validity and nomological validity from Roehrich's scale are acceptable (Roehrich, 2002). The three 'need for uniqueness' items were measured on a five-point response format.
The content validity of the questionnaire was addressed by involving two expert judges (during September 2004) to evaluate whether the scale items in the questionnaire adequately covered the domain of fashion innovativeness. The questionnaire (only available in English) was pre-tested among 10 female respondents in the Menlyn Shopping Centre at YDE and RJL stores during September 2004. The interviewer alerted respondents to their involvement in a preliminary test of the questionnaire, enlisting the respondents as collaborators in the refinement process. Overall, the survey questions proved to be understandable and meaningful to the target population. All that was necessary was to correct a few spelling errors.

One way to ensure reliability is to use measures that have proven their reliability in previous research (Babbie \& Mouton, 2001:122). For this reason established scales were used, as discussed earlier. Furthermore, reliability was calculated using Cronbach's coefficient alpha with a lower limit of 0,70 set for the Cronbach's alpha as suggested by Nunnally (1978:103). The reliability results of Cronbach's alpha are summarised in Table 1. It is important to note that two items were deleted from the DSI scale to increase the reliability from 0,66 to 0,71 .

From Table 1 it is evident that all the Cronbach's alpha coefficients of the constructs were above the recommended cut-off value, with values ranging between 0,71 and 0,85 . It can therefore be concluded that the

TABLE 1: SCALE RELIABILITY

\begin{tabular}{|c|c|c|c|}
\hline Construct & Scale items & $\begin{array}{l}\text { Alpha if } \\
\text { deleted }\end{array}$ & $\begin{array}{l}\text { Cronbach } \\
\text { alpha }\end{array}$ \\
\hline \multirow{4}{*}{$\begin{array}{l}\text { Fashion Innova- } \\
\text { tiveness }\end{array}$} & $\begin{array}{l}\text { In general, I am among the last in my circle of friends to buy a } \\
\text { new fashion item when it appears }\end{array}$ & 0,63 & \multirow{4}{*}{0,71} \\
\hline & Compared to my friends I own few new fashion items & 0,69 & \\
\hline & $\begin{array}{l}\text { In general, I am among the last in my circle of friends to know } \\
\text { the names of the latest fashions and styles }\end{array}$ & 0,65 & \\
\hline & I know more about new fashions before other people do & 0,64 & \\
\hline \multirow{6}{*}{$\begin{array}{l}\text { Fashion opinion } \\
\text { leadership }\end{array}$} & In general, I never talk to my friends about the latest fashions & 0,71 & \multirow{6}{*}{0,74} \\
\hline & $\begin{array}{l}\text { When I talk to my friends about the latest fashions I am able to } \\
\text { share a great deal of information about it }\end{array}$ & 0,66 & \\
\hline & $\begin{array}{l}\text { During the past six months, I have told many people about the } \\
\text { latest fashions }\end{array}$ & 0,71 & \\
\hline & $\begin{array}{l}\text { Compared to my circle of friends, I am very likely to be asked } \\
\text { about new fashions }\end{array}$ & 0,67 & \\
\hline & $\begin{array}{l}\text { In discussions of the latest fashions, my friends tell me about the } \\
\text { latest trends }\end{array}$ & 0,79 & \\
\hline & $\begin{array}{l}\text { Overall, in all of my discussions with friends and neighbours, I } \\
\text { am often used as a source of advice }\end{array}$ & 0,69 & \\
\hline \multirow{3}{*}{$\begin{array}{l}\text { Product involve- } \\
\text { ment in clothing } \\
\text { fashion }\end{array}$} & I have a strong interest in new fashions & 0,83 & \multirow{3}{*}{0,79} \\
\hline & I usually know where to get a good price on new fashions & 0,70 & \\
\hline & I usually know where to shop for certain new fashions & 0,59 & \\
\hline \multirow{3}{*}{$\begin{array}{l}\text { Need for fash- } \\
\text { ion uniqueness }\end{array}$} & I am usually among the first to try new fashions & 0,73 & \multirow{3}{*}{0,85} \\
\hline & I know more than others on latest new fashions & 0,88 & \\
\hline & I try new fashions before my friends and neighbours & 0,75 & \\
\hline
\end{tabular}


four derived scales are reliable and compared well with reported alpha coefficients in other consumer research measuring the same constructs (Feick \& Price, 1987; Mittal \& Lee, 1989; Goldsmith et al, 1998; Roehrich, 2002).

\section{Sampling and data collection}

The target population of the study consisted of females in the Pretoria region. A female sample was chosen for a number of reasons: there appears to be a connection between fashion innovativeness and females; and evidence shows that females are more concerned with beauty, appearance and fashion (Beaudoin et al, 2003). Females are thus considered to be fashion conscious and are likely to be innovators in the context of the fashion industry.

From the target population, the sampling frame was identified as females shopping at Young Designers Emporium (YDE) and RJL in the Menlyn Shopping Centre. A convenience sampling design was used to draw a sample of 120 females from the sampling frame (60 from YDE and 60 from RJL). This exercise was regarded as a pilot study. The data were collected by means of self-administered questionnaires distributed to females in the YDE and RJL stores during the four-week research period (October 2004). All females entering the afore-mentioned stores on Wednesdays and Thursdays were asked to complete the questionnaire in store. The effective response rate was $82,6 \%$ (100 completed questionnaires).

Of the female sample population, five per cent have a Grade 10 qualification, 42\% a Grade 12 education, and $53 \%$ some form of post-school qualification (degree/diploma or postgraduate/higher diploma). A total of $41 \%$ of the sample population earn less than R2000 per month. Of the 59\% who earn more than R2000 per month, a total of five per cent earn R15000 or more per month. In the pre-testing of the questionnaire, the age question proved to be a very sensitive issue with the women. A decision was made not to include the age question in the survey, to limit the possible negative impact on the response rate. It was, however, observed by the fieldworker that mainly young females (estimated to be below the age of 30 years) entered YDE and RJL. This is in line with these stores' brand, image and the type of clothing they sell.

\section{RESULTS}

The data were encoded numerically in MS Excel and statistically analysed and computed in SPSS 11.0.

\section{TABLE 2: MEAN VALUES OF SUB-SCALES}

\begin{tabular}{|l|c|}
\hline Sub-scales & Mean values \\
\hline Consumer innovativeness (DSI) & 3,43 \\
\hline Opinion Leadership & 3,47 \\
\hline Fashion involvement & 4,03 \\
\hline Need for uniqueness & 3,43 \\
\hline
\end{tabular}

Table 2 presents an overview of the mean values of the four sub-scales.

As can be seen from Table 2, three sub-scales have similar mean values (ranging from 3,43 to 3,47 ). These values indicate strong fashion innovativeness, fashion opinion leadership and a need for fashion uniqueness within the respondent group. The highest average $(4,03)$ is reported for the fashion involvement sub-scale. This suggests that involved consumers exhibit feelings of interest, pleasure and enthusiasm toward the fashionable clothing items sold in YDE and RJL. This is borne out of the observation that the typical shopper at these stores takes time and effort when selecting clothes. The involvement sub-scale also typically depicts consumers who place a great deal of emphasis on their clothing. As mentioned in the literature review, consumers' involvement in fashion clothing can be viewed as a continuum ranging from total attachment to fashion clothing and related activities (high involvement) to complete detachment (low involvement). The high mean value shows high involvement on the past of the respondents for this study.

For the testing of the hypotheses, the significance criterion was set at $p<0,05$, in other words at least 95\% confidence. Hypotheses 1, 2 and 3 each measure a positive correlation between two variables and it was anticipated that Pearson Product Moment Correlation tests would be conducted. However, two assumptions underlie Pearson Product Moment Correlation tests, namely the existence of normality and linear relationships (Diamantopoulos \& Schlegelmilch, 1997:203). The assumption for normality was tested for all the construct groups (fashion innovativeness, fashion opinion leadership, product involvement in clothing fashion and need for fashion uniqueness) using the Kolmogorov-Smirnov test and the results showed that the data were not normally distributed. The assumption of linear relationships was visually observed through scatter plots, and here the observations showed a non-linear relationship. Since the assumptions of normality and linearity were violated in all three cases, a decision was made to use the nonparametric alternative, Spearman's Rank Order Correlation, to test the following hypotheses:

$\mathrm{H}_{1}$ : Consumer fashion innovativeness is positively correlated with fashion opinion leadership.

$\mathrm{H}_{2}$ : Consumer fashion innovativeness is positively correlated with product involvement in clothing fashion.

$\mathrm{H}_{3}$ : Consumer fashion innovativeness is positively correlated with a need for fashion uniqueness.

The results of the Spearman's Rank Order Correlation tests for the above-mentioned hypotheses are presented in Table 3.

The Spearman's Rank Order Correlation results (see Table 3) showed positive relationships with moderate associations between fashion innovativeness and fashion opinion leadership, product involvement in clothing fashion and need for fashion uniqueness ( $r$ values between 0,50 and 0,57 ) - providing support for the proposed model shown in Figure 1 . The squared 
TABLE 3: SPEARMAN'S RANK ORDER CORRELATIONS

\begin{tabular}{|l|c|c|c|}
\hline & Opinion leadership & Product involvement & Need for uniqueness \\
\hline $\begin{array}{l}\text { Domain Specific Innovativeness } \\
\text { [Correlation Coefficient (r)] }\end{array}$ & 0,556 & 0,575 & 0,508 \\
\hline$p$-value & 0,00 & 0,00 & 0,00 \\
\hline
\end{tabular}

correlation coefficient indicates that $30,9 \%$ of fashion innovativeness is explained by the variation in fashion opinion leadership, $33 \%$ by the variation in product involvement in clothing fashion and $25,8 \%$ by the variation in need for fashion uniqueness. From the significant $p$-values, one can conclude that there is a relationship between fashion innovativeness and fashion opinion leadership, product involvement in clothing fashion and need for fashion uniqueness. This shows construct validity owing to the logical relationship among the variables (Babbie \& Mouton, 2001:123). The null hypotheses were thus rejected, as there is support for $\mathrm{H}_{1}, \mathrm{H}_{2}$ and $\mathrm{H}_{3}$.

\section{IMPLICATIONS FOR MANAGEMENT}

The research findings support previous findings, which indicate that opinion leadership, product involvement and need for uniqueness are positively correlated with domain innovativeness (Goldsmith et al, 1996; Goldsmith et al, 1998; Roehrich, 2002). The findings of this study relate to the fashion domain, showing that fashionable clothing is a possession that occupies an important position in society, especially among innovators. The cyclical nature of fashion implies that people are continually drawn into new styles, with innovators placing a great deal of emphasis on the latest fashion.

The research finding from $\mathrm{H}_{1}$ suggests that consumer fashion innovators are very likely to be fashion opinion leaders and they therefore represent a valuable market segment for future marketers to target. Managers in the fashion industry should attempt to create awareness among innovators, because other consumers turn to them for advice regarding the latest fashion trends. Awareness can be created through various sources such as unique clothing, creative advertising, direct communication with regular shoppers, and presence in the media and at fashion events. Fashion opinion leaders influence the adoption and diffusion of fashions within a social group. The positive correlation between consumer fashion innovativeness and fashion opinion leadership indicates that an exploration of fashion opinion leadership should provide an increased understanding of the behavioural traits of consumers.

From the positive correlation between consumer fashion innovativeness and product involvement in clothing fashion $\left(\mathrm{H}_{2}\right)$, it is apparent that innovators are likely to be associated with greater involvement in fashion products. It is apparent that consumer innovators are motivated to talk about the product because of their involvement with it. Managers should remember that individuals with greater purchasing involvement tend to know where to shop for certain items and where to get reasonably priced products. The finding also indicates that consumer innovators are a very promising market to serve, because of their strong interest in new fashions. This implies that they are willing and eager to spend more time shopping for clothes and spend more money on clothes than other consumers. Fashion retailers should therefore focus on designing clothing that is customised to the preferences of these consumers. This market segment, in general, is very aware of the different offerings by retailers, implying that managers should react to innovators' needs and wants in a proactive and dynamic way.

Marketing experts acknowledge that innovativeness has a substantial impact on consumer behaviour (Muzinich et al, 2003). The positive association between consumer fashion innovativeness and need for fashion uniqueness $\left(\mathrm{H}_{3}\right)$ suggests that consumers who are regarded as highly innovative tend to reveal a need for uniqueness. This signals to managers in the fashion industry that they should design unique, customised offerings in order to fulfil the needs and wants of innovative consumers. These consumers express clear needs that are different from the majority and it is thus the task of the manager to respond dynamically to these needs.

\section{LIMITATIONS AND FUTURE RESEARCH}

It is important to note that the results of this study cannot be generalised to all female consumers. The non-probability convenience sample makes the findings representative only of females shopping at YDE and RJL in the Menlyn Shopping Centre in Pretoria. At most the survey can be seen as a pilot study in the field of consumer fashion innovativeness among females.

Future research should systematically extend the approach of profiling fashion innovators. Data from a more representative female sample will enhance knowledge of consumer fashion innovativeness. Male fashion innovators, or the unique ways in which consumer innovators react to marketing mix variables such as advertisements, sales promotion or changes in price or distribution, could also be studied. There is also a need to investigate relationships among innovativeness and other constructs of interest, such as media usage and brand sensitivity. Fashion clothing has important economic and social significance in many societies and should be a focus of many more studies. 


\section{REFERENCES}

ALPERT, F. 1994. Innovator buying behavior over time. Journal of Product and Brand Management 3 (2):50-62.

AUTY, S \& ELLIOTT, R. 1998. Fashion involvement, self-monitoring and the meaning of brands. Journal of Product and Brand Management 7(2):109-123.

BABBIE, E \& MOUTON, J. 2001. The practice of social research. Oxford University Press. Cape Town. South Africa.

BAUMGARTEN, SA. 1975. The Innovative Communicator in the Diffusion Process. Journal of Marketing Research 12(February):12-18.

BEARDEN, WO, NETEMEYER, RG \& MOBLEY, MF. 1993. Handbook of marketing scales. SAGE Publications. Newbury Park.

BEAUDION, P, MOORE, MA \& GOLDSMITH, RE. 1998. Young fashion leaders' and followers' attitudes toward American and imported apparal. Journal of Product and Brand Management 7:193-207.

BEAUDION, P, LACHANCE, MJ \& ROBITAILLE, J. 2003. Fashion innovativeness, fashion diffusion and brand sensitivity among adolescents. Journal of Fashion Marketing and Management 7(1):23-30.

BROWNE, BA \& KALDENBERG, DO. 1997. Conceptualizing self-monitoring: links to materialism and product involvement. Journal of Consumer Marketing 14(1):31-44.

BURNS, DJ \& WARREN, HB. 1995. Need for uniqueness: shopping mall preference and choice activity. International Journal of Retail and Distribution Management 23(12):4-12.

CHAU, PYK \& HUI, KL. 1998. Identifying early adopters of new IT products: a case of Windows 95. Information and Management 33(5):225-30.

CHILDERS, TL. 1986. Assessment of psychometric propreties of an opinion leadership scale. Journal of Marketing Research 23(May):184-188.

DARLEY, WK. 1999. The relationships of antecedents of search and self-esteem to adolescent search effort and perceived product knowledge. Psychology and Marketing 16(5):409-428.

DIAMANTOPOULOS, A \& SCHLEGELMILCH, BB. 1997. Taking the fear out of data analysis. London. Dryden Press.

FEICK, LF \& PRICE, LL. 1987. The market maven: A diffuser of marketplace information. Journal of Marketing 51(January):83-97.

FLYNN, LR \& GOLDSMITH, RE. 1993. Identifying innovators in consumer service markets. Service Industries Journal 13(3):97-109.

GOLDSMITH, RE. 1998. Some characteristics of wine innovators. International Journal of Wine Marketing 10 (1):5-12.

GOLDSMITH, RE, D'HAUTEVILLE, F \& FLYNN, LR. 1998. Theory and measurement of consumer innovativeness: A transnational evaluation. European Journal of Marketing 32(3/4):340-353.

GOLDSMITH, RE \& EMMERT, J. 1991. Measuring product category involvement: a multitrait, multimethod study. Journal of Business Research 23:363371.

GOLDSMITH, RE \& FLYNN, LR. 1992. Identifying innovators in consumer product markets. European
Journal of Marketing 26(12): 42-55.

GOLDSMITH, RE \& HOFACKER, CF. 1991. Measuring Consumer Innovativeness. Journal of the Academy of Marketing Science 19(3): 209-221.

GOLDSMITH, RE, MOORE, MA \& BEAUDION, P. 1996. The self-concept of fashion leaders. Clothing and Textiles Research Journal 14:242-248.

GOLDSMITH, RE \& NEWELL, SJ. 1997. Innovativeness and price sensitivity: managerial, theoretical and methodological issues, Journal of Product and Brand Management. 6(3):163-174.

GOLDSMITH, RE \& STITH, MT. 1992. The social values of fashion innovators. Journal of Applied Business Research 9(1):10-18.

GOLDSMITH, RE, STITH, MT \& WHITE, JD. 1987. Race and sex differences in self-identified innovativeness and opinion leadership. Journal of Retailing 63 (4):411-25.

GUTMAN, J \& MILLS, MK. 1982. Fashion life style, self-concept, shopping orientation, and store patronage: an integrative analysis. Journal of Retailing 50 (2):64-86.

HA, Y \& STOEL, L. 2004. Internet apparel shopping behaviors: the influence of general innovativeness. International Journal of Retail and Distribution Management 32(8):377-385.

HAWKINS, DI, BEST, RJ \& CONEY, KA. 2001. Consumer behavior: Building marketing strategy. $8^{\text {th }}$ ed. Irwin McGraw-Hill. Boston. USA.

HORRIDGE, P \& RICHARDS, L. 1984. Relationship of fashion awareness and apparel economic practices. Home Economics Research Journal 13(2):138-152.

IM, S, BAYUS, BL \& MASON, CH. 2003. An empirical study of innate consumer innovativeness, personal characteristics, and new product adoption behavior. Journal of the Academy of Marketing Science 31 (1):61-73.

KAISER, S. 1997. The Social Psychology of Clothing, $2^{\text {nd }}$ ed. Fairchild. New York.

KIM, HS, DAMHORST, ML \& LEE, KH. 2002. Apparel involvement and advertisement processing. Journal of Fashion Marketing and Management 6(3):277-302.

LEUNG, L. 1998. Lifestyles and the use of new media technology in urban China. Telecommunications Policy 22(9):781-90.

MARTINEZN E, POLO, Y \& FLAVIAN, C. 1998. The acceptance and diffusion of new consumer durables: Differences between first and last adopters. Journal of Consumer Marketing 15(4):323-342.

McCARTY, M, O'SULLIVAN, C \& O'REILLY, S. 1999. Pre-identification of first buyers of a new food product. British Food Journal 14:242-248.

MIDGLEY, DF \& DOWLING, GR. 1978. Innovativeness: The concept and its measurement. Journal of Consumer Research 4(2):229-242.

MITTAL, B \& LEE, M.1989. A causal model of consumer involvement. Journal of Economic Psychology 10:363-389.

MUZINICH, N, PECOTICH, A \& PUTREVY, S 2003. A model of the antecedents and consequents of female fashion innovativeness. Journal of Retailing and Consumer Services 1:1-13.

NUNNALLY, J. 1978. Psychometric Theory. $2^{\text {nd }}$ ed. New York. McGraw-Hill.

O'CASS, A. 2004. Fashion clothing consumption: an- 
tecedent and consequences of fashion clothing involvement. European Journal of Marketing 38(7):869882.

PARKER, SP, HERMANS, CM \& SCHAEFER, AD. 2004. Fashion consciousness of Chinese, Japanese and American teenagers. Journal of Fashion Marketing and Management 8(2):176-186.

PASTORE, M. 1999. The lifestyle of the online shoppers,available at: http://cyberatlas.internet.com (accessed 8 December 2005).

ROBERTSON, TS. 1971. Innovative behavior and communication. Holt, Rinehart and Winston. New
York.

ROEHRICH, G. 2002. Consumer innovativeness, concepts and measurements. Journal of Business Research May:1-7.

ROGERS, EM. 1995. Diffusion of Innovation. $4^{\text {th }}$ ed. New York. The Free Press.

SUMMERS, JO. 1971. Generalized Change Agents and Innovativeness. Journal of Marketing Research 8 (August):313-316.

TIGERT, D, KING, C \& RING, L. 1980. Fashion involvement: a cross-cultural analysis. Advances in Consumer Research 17:17-21. 